\title{
Improving School Quality Through Featured Program in Madrasah Ibtidaiyah Tarbiyatul Islamiyah Winong
}

\author{
Parmanita Hesti Puspitorini ${ }^{1}$, Zainal Airifn ${ }^{2}$, Badi'atul Islami ${ }^{3}$ \\ \{parmanitahesti.2020@student.uny.ac.id ${ }^{1}$, zainal_arifin@uny.ac.id ${ }^{2}$, \\ badi'atulislami.2020@student.uny.ac.id $\left.{ }^{3}\right\}$ \\ Faculty of Education, Universitas Negeri Yogyakarta
}

\begin{abstract}
This research was conducted to find out about the featured program for improving the quality of schools in Madrasah Ibtidaiyah Tarbiyatul Islamiyah Winong, Pati, Central Java, Indonesia. The school has now succeeded in becoming one of the best schools in Winong subdistrict because it has qualities that is shown by its achievements and have been recognized by the surrounding community. The data was obtained through the qualitative method with a case study approach include interviews, observation, and documentation. The results show that school quality improvement occurs when the school held some featured programs such as (1) the tahfidz Al-Qur'an featured program, (2) the varies of the extracurricular program, and (3) interest and talent assessment for pra-students at the school.
\end{abstract}

Keywords: School Featured Program, School Quality, Madrasah Ibtidaiyah Tarbiyatul Islamiyah Pecangaan Winong Pati

\section{Introduction}

Education is one of the important things to improve the quality of human resources. In meeting educational needs, schools become one of the places in facilitating students to gain knowledge and develop their skills. The implementation of education based on Government Regulation Number. 17 of 2010 is an activity about implementing components of the education system which is divided into several levels such as primary, secondary, and junior college to achieve national education goals. Primary education levels in Indonesia include Elementary School and Madrasah Ibtidaiyah. Elementary School according to Government Regulation Number. 17 of 2010 is an educational unit that organizes formal education with the aim to the public and implemented under the Ministry of Education and Culture, while Madrasah Ibtidaiyah is an educational unit that organized by public education with Islamic religious orientation and implemented under the auspices of the Ministry of Religion [9]. Education through schools is expected to make Indonesia able to compete globally, this can be done through the improvement of existing human resources. 
The education unit will be able to develop human resources if the institution itself has a good quality. Based on research, the quality of the school is important because it relates to one's future economic income after they having a job [4]. In addition, despite affecting one's income when they have a job in the future, the quality of school at the elementary level will influence the performance of students later when students are in the upper secondary level, which means students who receive good quality learning at the elementary level, they will be easy and able to face and overcome obstacles in the upper secondary level [8]. This quality of schools will be obtained by students depending on their respective schools, both public and private schools.

Private schools are considered to have their own attractiveness because they have better quality than public schools [5]. It is also shown from the research that the market demand to choose schools with good quality ultimately makes many private schools appear because it is considered to have better quality than public schools, in addition, private schools sometimes have their own specificities such as schools with religious curriculum, so this attracts the interest of the public or parents to send their children to the place [22]. The quality of the school can be seen from the excellent program they have. Each school certainly has a different program that becomes an icon and a characteristic that distinguishes it from each other schools. Examples of programs owned by schools are childfriendly programs that based on research have an influence on improving the quality character of early childhood [17]. Based on this research, the school's program will certainly have an impact on the resources and quality of the school.

One of the private schools that has good quality and becomes a favorite institution for parents to send their children is MI Tarbiyatul Islamiyah (Taris) in Winong Pati Subdistrict, Central Java, Indonesia. This school, able to improve the quality of what was originally a normal school became one of the best quality schools in Winong subdistrict, Pati. The curriculum applied is a religiousbased curriculum such as MI in general. However, MI Taris remains the choice of the community to send their children to this school. Mi Taris' programs are one of the factors in improving the quality of schools so that they can become excellent schools that excel. Researchers want to know the program that changed MI Taris which was an ordinary MI into a superior MI school in Winong sub-district.

The purpose of this study is 1) Analyzing the flagship program owned by MI Taris Winong. 2) Analyzing the quality improvement obtained by MI Taris Winong through the featured program applied. And of course, this research has benefits such as 1) Theoretical benefits, can contribute theory and provide references for other schools able to implement excellent programs in schools. 2) Practical benefits, this research can be used to provide input to schools to be able to improve their quality and values by organizing excellent programs in schools. Based on this research, it will be explained that the quality improvement of schools that were ordinary schools became good quality schools through the featured program at MI Taris Winong, Pati.

\section{Research Methods}

This study was held using a qualitative research method with a case study approach. Qualitative research aims to understand phenomena by focusing on the overall picture and understanding the 
situation in depth [1]. Qualitative research has tentative and temporary properties, it's meant that when researchers are having a research in the field, the focus will be developed because it will meet and get things more in-depth than before [23]. The case study approach is qualitative research that focuses on one thing such as focusing on one individual, group, organization or focus on a program with the aim to obtain a description and understanding of a situation [1].

Data collection in this study was conducted by interviewing techniques, documentation, and observation to the school directly [13]. The research instrument that was used is the researcher himself. The object of the research is Madrasah Ibtidaiyah Pecangaan Winong, Pati by involving the principal as a key informant and additional informants are teachers. Then, researchers collect the data and analyze it. The process of data analysis is carried out through several stages of data collection, data reduction is necessary to sort the data results from the collection to be researched, presentation of data, and describe it in an understandable conclusion [19]. Therefore, in this research will be conducted in-depth and at the end of the research will be presented in the form of images, tables, or graphs.

\section{Results and Discussion}

After interviewing the principal and teachers, it was informed that MI Tarbiyatul Islamiyah Pecangaan Winong school was founded in 1962. At that time the school was only the place to learn Al-Qur'an recitation, then developed its students and it stood as Madrasah Ibtidaiyah Tarbiyatul Islamiyah Winong. In 2005, the state of the classroom only had 4-5 students in a class. Teachers need the effort to go around looking for children from one house to another in order to get students who want to study at the school. This happened because the surrounding people in the community was hardly interested and does not have the trust to send their children there. MI Taris was untrusted by the community and this was exacerbated by the building at that time that was not feasible.

The year 2007 was the turning point of MI Tarbiyatul Islamiyah Winong where at that time the management agreed to create a different program from other general MI in the sub-district. The course of the program provides good results for the school. This can be seen from the increasing number of students, based on documentation data in the school year 2020/2021 the school has about 370 students, this figure is quite significant compared to the situation in 2007.

Table 1 : Number of students for the 2020/2021 school year

\begin{tabular}{lc}
\hline Grade & Number of Students \\
\hline $1^{\text {st }}$ Grade & 63 \\
$2^{\text {nd }}$ Grade & 56 \\
$3^{\text {rd }}$ Grade & 53
\end{tabular}




\begin{tabular}{lc}
$4^{\text {th }}$ Grade & 53 \\
$5^{\text {th }}$ Grade & 80 \\
$6^{\text {th }}$ Grade & 65 \\
Total & 370 \\
\hline
\end{tabular}

In addition, based on the observations of researchers in the school, MI Taris now has a very decent building and adequate school facilities. When the researchers made observations there, the school building consisted of two floors and stood firm without visible flaws, a clean schoolyard, and available facilities for students such as libraries, student health unit, canteens, volleyball courts, and other student learning support facilities that are quite complete.

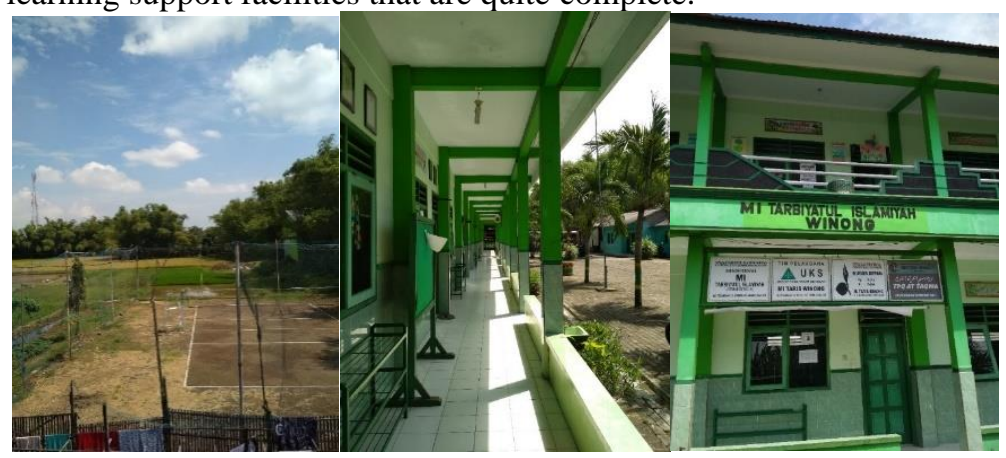

Fig.1.School Facilities

MI Taris also has many achievements, based on the results of documentation of achievements that have been achieved are as follows:

a. Academic achievements in recent:

Academic achievement in 2020:

1. Gold for MIPASA (Mathematic, Science, Social Science, and Islamic Science) in national level

2. Silver and bronze MIPASA (Mathematic, Science, Social Science, and Islamic Science) national level, Central Java \& Yogyakarta

3. Silver and bronze PPO (Science Olympiad Builders Association), Central Java \& Yogyakarta

Academic achievement in 2021:

1. MIPASA National in 2021 got silver and bronze

2. Bronze for social science national level MIPASA 2021 
3. Bronze for Banin Olympiad of Science Central Java and Yogyakarta

b. Non-academic achievements in recent:

Non-academic achievements in 2019:

1. 3rd place MTQ (Al-Qur'an Recitation) Porsema Central Java Province in 2019

2. 1st winner of MTQ Student XXV branch of SD/MI (Elementary School) Pati District Level in 2019

3. 3rd winner man for general tilawatil qur'an MTQ (Al-Qur'an Recitation) XXVIII Pati District in 2019

4. Pandhawa championship for man class I in 2019

5. Silat championship

Non-academic achievements in 2020:

1. $1^{\text {st }}$ winner tilawah (Al-Qur'an Recitation) Pati District 2020

2. 2nd place adzan and iqamah National level 2020
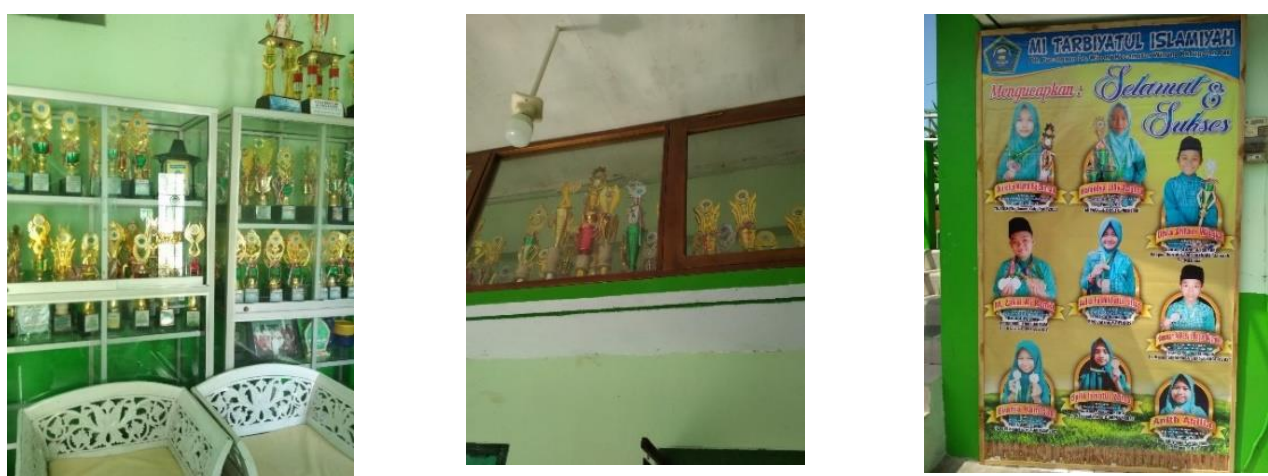

Fig.2. Photo of MI Taris Winong Pati student's achievement

In 2021, MI Tarbiyatul Islamiyah managed to get the rank of 6th place of achievements in Central Java from 225 MI schools who participated in the program by obtaining academic achievements about 28 , non-academic achievements about 4 with a total of 32 achievements. This can be seen in the MI achievement list in figure as follows: 


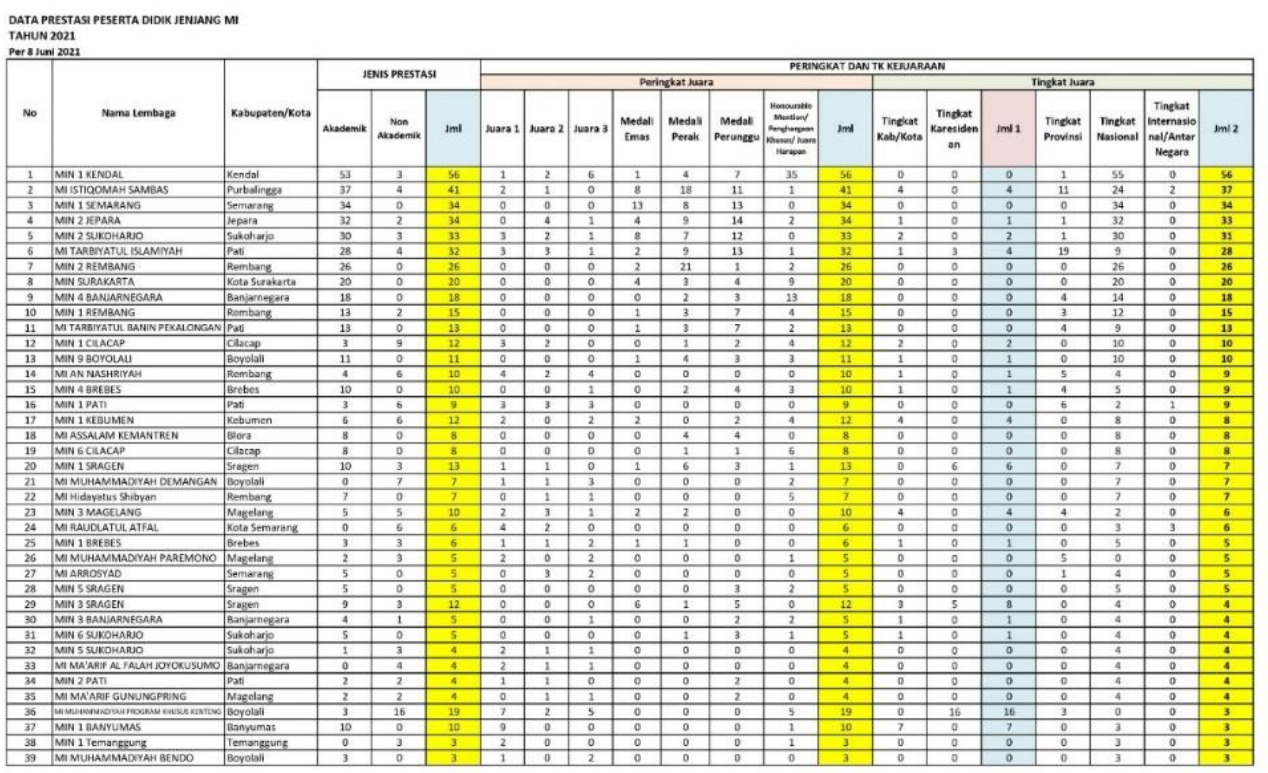

Fig.3. List of Achievements of Madrasah Ibtidaiyah In Central Java in 2021

In addition, based on the results of interviews with the principals and teachers, MI Taris was able to develop itself to be able to improve the quality of the school by creating several excellent programs that proved effective in bringing MI into an outstanding and good quality school. The featured programs include:

\section{Tahfidz Al-Qur'an School Program}

MI Taris became a great quality school because of the excellent program that is tahfidz AlQur'an program. According to Farid Wadji, tahfidz is a process or activity carried out to memorize the Qur'an so that the reading in the holy verses of the Qur'an can be remembered outside the head, as for the person who memorizes the Qur'an is called al-hafiz [11]. MI Taris in 2007 began to organize tahfidz programs for children around the school who want to learn and memorize the Qur'an.

Tahfidz school program in MI is divided into two programs, namely regular program and cottage program. For regular programs carried out like normal schools in general, like an entering school at 07.00 and returning at 15.00 with a percentage of general learning $50 \%$ and religious learning $50 \%$ while for tahfidz programs in the cottage is carried out within 24 hours every day with a percentage of $70 \%$ religious learning and $30 \%$ general learning. Since the tahfidz program was 
implemented, schools have seen an increase in the number of students quiet drastically. In the 2020/2021 school year in one level, there are two classrooms with a total of 26-27 students per class.

If we look at the population statistics, Indonesian society is dominated by Muslims. While in Pati, Central Java in 2015 based on data from the Central Java Provincial Statistics Agency there were as many as 1,173,337 people who counted as Muslims, this shows that Muslims in Pati have a considerable number [2]. Based on the data is not wrong if the public is interested in the school program tahfidz. Moreover, according to Islamic beliefs by memorizing the Qur'an there are its virtues, the virtues of memorizing Qur'an are as follows [18]:

1. Memorizing the Qur'an will get a great reward

2. Increase one's faith

3. Allah will elevate the degree of readers of the Qur'an

4. The best busyness is when one reads the Qur'an

5. Always accompanied by angels

6. The Qur'an will be a helper on the Day of Resurrection

7. Parents who have the children that memorizing the Qur'an will be crowned on the Day of Resurrection

In addition to some of these things, there are other benefits in memorizing the Qur'an that will have an impact on the psychological reader such as will gain peace of mind, as a remedy and anxiety in the self, and memorization of the Qur'an can prevent delinquency in adolescents [15]. With some wisdom obtained from the memorization activities, in the end, the people who follow the religion of Islam will be interested in sending their children to school with a program tahfidz Al-Qur'an.

Based on interviews with principals and teachers in MI, since the Qur'an tahfidz program was implemented, the enthusiasm of the community, especially the parents of students, is very great to be able to send their children to MI Taris. Every year when the registration is opened, MI always gets many new students even the quota more than enough. This proves that tahfidz's featured program can be an attraction and can improve the quality and quantity of the school.

\section{Extracurricular Program}

In addition to the tahfidz program, another interesting activity of MI Taris is the existence of varied extracurricular programs provided by the school. Extracurricular programs are activities related to learning and are usually carried out after lesson hours with the aim to develope students' interests and talents related to sports, skills, art, scouting, and others [24]. Research shows that extracurricular programs can improve achievement and positive impact on school students [6]. According to Bowen and Greene stated that extracurricular activities such as sports can be a place for people to gathering as well as a place to socialize [3]. In addition, extracurricular activities such as joining the club, occupying leadership positions in schools, leading orientation, and conducting other extra non-academic activities have a positive impact on academic performance, even have 
great achievements in graduation, as well as get a high GPA [25]. This is also supported by other research on extracurriculars that have a positive and consistent impact on student outcomes including social and academic [16].

In MI Taris, the extracurricular program is divided into two:

a. Academic extracurricular programs: that is to provide Olympic programs that can help academic students such as mathematics and science.

b. Non-academic extracurricular programs: such as extracurricular art of reading the Qur'an, drum band, martial arts silat, karawitan (Java Music), scouting, dance, tennis, and badminton.

This extracurricular program is quite interesting for the public to enroll their children in MI. Extracurriculars in the school are pretty much and one of them is religious extracurricular programs such as the art of reading the Qur'an. Research said that the implementation of religious extracurriculars can have a positive impact on learners so that they can live the value of Islam and prevent them from bad influences [10]. The benefits of extracurricular implementation are that it can help students in socializing such as adding friendships with other students, developing selfskills, and increasing academic potential [14]. The benefits will help students in improving hard skills and soft skills and these are important for student's needs in the future in living real life and having a job.

With the implementation of extracurricular programs, MI Taris obtained various achievements from the sub-district to national levels in the academic and non-academic fields. The results certainly improve the quality of the school and become the attraction of the community to send their children to get positive activities while in school.

\section{Interests and Talents Test Program}

For the elementary school level, the talent interest test conducted by MI Taris aims to map students according to their abilities or potentials. This talent interest test is rarely known to be done by primary schools in general. In fact, the role of this test of interest and talent is important to help students explore and pursue their potential. The test of interest and talent will make students know their potential both from their advantages and disadvantages [26]. There is research that shows that learning interests and talents have an influence on students' learning outcomes [7]. Based on other research also explained that the high interest of students towards something such as students' interest in learning will contribute to the academic performance of students [12]. Therefore, by understanding more deeply, the teacher will know to direct students according to their abilities and interests. With students interested and able, this can affect academic and non-academic achievements in their learning activities in school.

The interviews results with teachers, interest and talent tests conducted for all new students, it is important to know what action will be taken next to the potential of the students. The test is conducted through questionnaires and interviews to parents to be able to provide explanations and pictures of children thoroughly. After the process of filling out questionnaires and interviews, 
students are grouped and directed according to their potential. This action is expected to support students to get achievements according to their abilities. Based on the three programs, this research can be summarized into the chart as follows:

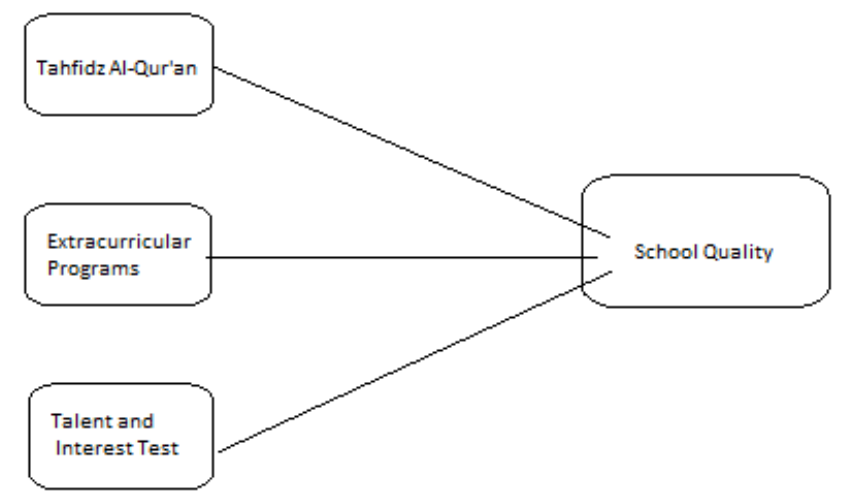

Fig.4. Improving School Quality Through Mi Taris Winong's Featured Program

MI Taris Winong Pati has changed and improved the quality of schools from 2007 until grow as today. The improvement of quality is seen from adequate facilities and infrastructure, as well as the number of students who increase even each level has two classes from grades 1-6. In addition, MI Taris also obtained many achievements from academic achievements and non-academic achievements. In 2021 MI Taris managed to get 6th place out of 225 MI who participated in the program at the Central Java level with 28 academic achievements and 4 non-academic achievements so as to get a total of 32 achievements. This quality improvement occurs because since 2007 the school began to improve the quality through the procurement of excellent programs such as tahfidz program or memorization of the Qur'an which is divided into two different programs, namely regular programs and cottage programs. This tahfidz program becomes schools' featured program and is able to bring schools into schools that are favorited by the community in Winong Sub-district. This is supported by the majority of people who are Muslims so that interest in religious programs is also high.

In addition, another program available in schools is the after-school program or extracurriculars where students can follow according to their wishes and potentials. The extracurricular consist of activities related to academic and non-academic fields. This extracurricular program is useful to help students can interact with their friends as to help students in building social potentiality and also able to grow the skills and hard skills of students. Because of these extra activities, schools often get achievements both at the local and national levels.

The latter program is a talent interest test for the new students. This aims to map the potential and ability of students so that teachers can direct students to be able to excel according to their field. This talent and interest test are conducted on parents of students through interviews and 
questionnaires. After the test, the next step is to be given action by grouping and directing students according to their potential.

Through the featured programs, MI Taris is able to bring itself into a school that has its own value rather than the surrounding schools so that many people are interested in sending their children to school in MI. The value of this school is one of the differentiation strategies in marketing concepts that are rarely used by education management in schools [20]. Since it has a competitive advantage, MI has increased the quality, the number of students, achievements and also get many opportunities to improve the quality of infrastructure facilities in schools.

\section{Conclusion}

To improve the quality of schools, a strategy is needed through excellent programs that distinguish schools from others. This excellent program is considered effective in MI Taris Winong because the previously ordinary school and lack of adequate facilities can turn into a good quality school, this is shown from the increase in the number of students, the public interest to send their children there, and also the achievements of students both academic and non-academic. Improving the quality of schools occurs through the school's featured program, namely tahfidz (memorization of the Al-Qur'an), extracurricular class programs, and interest and talent test programs for the new students at MI Taris Winong. Based on the research, it can be concluded that to achieve quality, value is required thing that makes the school has a different advantage than other schools. By having differentiation programs, the school will attract people to study there. This research can be an insight for other private and public schools that want to organize education through excellent programs.

\section{References}

[1] Ary, Donald. Introduction To Research In Education. Australia: Wadsworth Cengage Learning. 2014.

[2] Badan Pusat Statistik Jakarta Pusat. Population By Regency/ Municipality and Religion in Jawa tengah Province, 2019. Jakarta Pusat: Badan Pusat Statistik. 2019.

[3] Bowen DH, Hitt C. History and evidence show school sports help students win. Phi Delta Kappan. 2016;97(8):8-12.

[4] Case AC, Yogo M. Does School Quality Matter? Returns to Education and the Characteristics of Schools in South Africa. SSRN Electron J. 2005;100(1).

[5] De Talancéa M. Private and public education: Do parents care about school quality? Ann Econ Stat. 2020;100(137):117-44.

[6] Eccles, J. S., \& Templeton, J. (2002). Chapter 4: Extracurricular and other after-school activities for youth. Review of research in education, 26(1), 113-180.

[7] Fadillah, A. Analisis minat belajar dan bakat terhadap hasil belajar matematika siswa. Mathline: Jurnal Matematika dan Pendidikan Matematika. 2016. 1(2), 113-122.

[8] Gould ED, Lavy V, Paserman MD. Immigrating to opportunity: Estimating the effect of school quality using a natural experiment on Ethiopians in Israel. Q J Econ. 2004;119(2):489-526.

[9] Government Regulations. 2010. Government Regulation (PP) on The Management and Implementation of Education on Higher Education. Jakarta: Secretary of State. 
[10] Hambali M, Yulianti E. Ekstrakurikuler Keagamaan Terhadap Pembentukan Karakter Religius Peserta Didik Di Kota Majapahit. Pedagogik. 2018;5(2):193-208.

[11] Hidayah N. Strategi Pembelajaran Tahfidz Al-Qur'an di Lembaga Pendidikan. Ta'allum J Pendidik Islam. 2016;4(1):63-81.

[12] James KPOLOVIE P, Igho JOE A, Okoto T. Academic Achievement Prediction: Role of Interest in Learning and Attitude towards School. Int J Humanit Soc Sci Educ [Internet]. 2014;1(11):73-100. Available from: www.arcjournals.org

[13] Kusmarni, Y. Studi Kasus. UGM Jurnal Edu UGM Press. 2012

[14] Lawhorn B. Extracurricular activities: The afterschool connection. Occup Outlook Q [Internet]. 2008;52(4):16. Available from: http://connection.ebscohost.com/c/articles/37197154/extracurricularactivities-afterschool-connection

[15] Masduki, Y. Implikasi Psikologis Bagi Penghafal Al-Qur’an. Medina-Te: Jurnal Studi Islam. 2018; 14(1), 18-35.

[16] [Marsh HW. Extracurricular Activities: Beneficial Extension of the Traditional Curriculum or Subversion of Academic Goals? J Educ Psychol. 1992;84(4):553-62.

[17] Nuraeni L, Andrisyah A, Nurunnisa R. Efektivitas Program Sekolah Ramah Anak dalam Meningkatkan Karakter Anak Usia Dini. J Obs J Pendidik Anak Usia Dini. 2019;4(1):20.

[18] Rasyid, M. M. Kemukjizatan Menghafal Al-Qur'an. Semarang: Elex Media Komputindo. 2015.

[19] Rijali A. Analisis Data Kualitatif. Alhadharah J Ilmu Dakwah. 2019;17(33):81.

[20] Sari LP. Strategi Diferensiasi. Dictio. 2018;147-79.

[21] Seow PS, Pan G. A Literature Review of the Impact of Extracurricular Activities Participation on Students' Academic Performance. J Educ Bus. 2014;89(7):361-6.

[22] Smith KB, Meier KJ. Public Choice in Education: Markets and the Demand for Quality Education. Polit Res Q. 1995;48(3):461.

[23] Soegiyono. Metode Penelitian Pendidikan. Edition 21th. Bandung : Alfabeta; 2015.

[24] Ubaidah S. Manajemen ekstrakurikuler dalam meningkatkan mutu sekolah. Al-Fikrah J Kependidikan Islam IAIN Sulthan Thaha Saifuddin [Internet]. 2014;5(11):150-61. Available from: https://media.neliti.com/media/publications/56738-ID-manajemen-ekstrakurikuler-dalam-meningkat.pdf

[25] Wang J, Shiveley J. The Impact of Extracurricular Activity on Student Academic Performance Office of Institutional Research California State University, Sacramento. 2009;1-19.

[26] Yulianti W. Aptitude Testing Berbasis Case-Based Reasoning Dalam Sistem Pakar Untuk Menentukan Minat Dan Bakat Siswa Sekolah Dasar. Rabit J Teknol dan Sist Inf Univrab. 2016;1(2):104-18. 